\title{
Computer Keyword Search Application For Bachelor Of Science In Information And Communicationstechnology Students Of The Cebutechnological University Daanbantayan Campus: Learning Exercise
}

\author{
Dr. Nikkithea Layon-Beduya, Sarrah Jean T. Rodrigo, John Mello S. Melendres, John Philip D. \\ Gastador, Mariel B. Pautan and Lea A. Pelorina
}

\begin{abstract}
The main objective of this study is to create an application that will help the Bachelor of Science in Information and Communications Technology students in their daily school activities to be more efficient and effective. The research was conducted at Cebu Technological University Daanbantayan Campus, Agujo, Daanbantayan, Cebu. The university is located at Barangay Agujo, Daanbantayan, Cebu Philippines is located along the highway, 128 kilometers from Cebu City going to the last town in the Northern part of Cebu Philippines. It deals expensive cost of internet use. The suggested method in the study is the use of the research instrument through questionnaires. This study investigates the efficiency of the said Offline Application.

The results showed that the students agreed to the proposed system the following findings are hereby stated. From the given questions of the Resources that are most commonly used reveals that questions numbered 1 and 2 got the weighted mean which falls on the rating interval of $2.51-3.50$ which is labeled "Often" means that the BSCIT students often use mobile phones and laptops. Questions numbered 3 and 4 got the weighted mean that falls on the rating interval of $1.51-2.50$ which is labeled "Sometimes" which implies that the BSICT student sometimes using personal computers and dictionaries.

An impact of using Offline Search Application reveals that all questions numbered 1. Advanced learning for the future studies, 2 Easier accesses with the aid of this system. , 3 mainly beneficial specifically for BSICT Students. , and 4 got the weighted mean which falls on the rating interval $2.51-3.50$ which is labeled "Often" means that these questions were often did by the students in learning. The Impacts of using Offline Search System got the average weighted mean which is $\mathbf{2 . 7 8}$ which means "Often".

Lastly, from the given question of Difficulties encountered in using other Offline Search Application reveals that the question numbered 6 Lack of data's coming from the server got the weighted mean, which falls on the rating $2.51-3.50$ which labeled "Often" means the students find most difficult. Questions numbered $1,2,3,4,5$, and 7 got the weighted mean which falls on the rating $1.51-2.50$ which labeled "Sometimes "means that the students find less difficult in encountering these in daily life in learning. The difficulties encountered in using other offline search system got the average weighted mean which is 2.39 which means "Sometimes".
\end{abstract}

Dr. Nikkithea Layon-Beduya, Cebu Technological University Daanbantayan Campus Daanbantayan, Cebu (Email : thea_rx@yahoo.com

Sarrah Jean T. Rodrigo, Cebu Technological University Daanbantayan Campus Daanbantayan, Cebu.

John Mello S. Melendres, John Philip D. Gastador, Mariel B. Pautan and Lea A. Pelorina, Cebu Technological University Daanbantayan Campus Daanbantayan, Cebu.
Based on the findings that have been gathered there are lots of resources that are commonly used in using this application, especially computer. There are also difficulties and impacts of using this application. We, the researchers concluded that using Offline Search Computer Application is efficient to use based on the result of the study. As a whole, the proposed application and the use of internet has a remarkable distinction. The difference of using internet from this application is truly beneficial to the students, teachers, and the future.

Keywords-Keyword search, application, Encountered, learning, resource, technology.

\section{INTRODUCTION}

These days every second counts, and you need to make the most of your limited time. There is less time, less space and the things that matters demand all of your attention. Offline Search System provides effective solutions to your language needs and by helping you find what you want; it will save your time and energy.

Da Kuang (The University of Western Ontario), suppose we have a topic category named "animal" with all animal-related web pages classified into it; we can simply search the keyword "worm" in the topic category and the results will be much better. Since it is Offline, the users might be able to search anything that is related to ICT information they need, they can be more productive by not spending money going to the internet cafes to search for information about their topic (Only related to ICT students). One of the advantages of this system is that at the time you spend less, because you do not have to wait for the internet to browse because you have your enough information. For example; to search for "worm" as the animal in the nature, it is an ambiguous query, since worm can also be mean as a computer virus. If we limit the search in the area of animal, we can search "animal worm". This is a topic-related query. However, the keyword "animal" may not match with the web pages that really talks about the animal worm but do not contain the keyword "animal".

Sergey Brin and Lawrence Page (The Anatomy of a Large-Scale Hyper textual Web Search Engine Computer Science Department, Stanford University, Stanford, CA 94305) the web creates new challenges for information retrieval. The amount of information on the web is growing rapidly, as well as the number of new users without an experience in the web 
research. People will most likely surf the web using its link graph, often starting with high quality human maintained indices such as Yahoo! or with search engines. Human maintained lists covers popular topics effectively but are subjective, expensive to build and maintain, slow to improve, and cannot cover all esoteric topics. Automated search engines that rely on keyword matching usually return too many low quality matches. To make matters worse, some advertisers attempt to gain people's attention by taking measures meant to mislead automated search engines. We have built a large-scale search engine which addresses many of the problems of existing systems. It makes especially heavy use of the additional structure present in hypertext to provide much higher quality search results. We chose our system name, Google, because it is a common spelling of googol, or 10100 and fits well with our goal of building very large-scale search engines.

As of today, we all know that our generation is in electronic age, because of the technologies that provides existing application and search system that can help our daily life and in school works. There are so many kinds of Search System that are existing today. Just like the famous Google.com. Maybe everything on earth that we want to know about anything is on the said website. We can easily get the information we want to know. The purpose of this study is to enhance the educational skill. As we all experience today, this system is the most commonly used in the fast growing high technology world. Usually, this system can be used without internet connection. Mostly of the jobs today used this system to make their work easy, just like teachers they need to use this system that contains all the information for their daily lessons. In addition, there are a lot of students that can benefit with this system.

As we all know, there are a lot of information that are stored in the Search System. Internally, there are many servers and databases that used to store, provide, and gather information that people needs. The findings of the study support the conclusion that integrating offline Search System can positively help the interactions of the learners in college. Most of the existing web search system such as Google and Bing are in the form of keyword based search. Typically, after the user issues a query with the keywords, the Search System will return into a flat list of result. When the query issued by the users is related to a topic, only the keyword matching may not accurately retrieve the whole set of web pages in that topic.

\section{THE PROBLEM}

The main purpose of this system is to determine whether it benefits the students for their learning and their studies of BSICT III in Cebu Technological University Daanbantayan Campus, Agujo, Daanbantayan, Cebu.

\section{MATERIALS AND METHODS}

The main instrument used in the system was the questionnaire that consisted two parts: Part I was the profile of the respondents and Part II was the survey part.

The questionnaire was made and prepared by the researchers themselves and was checked and approved by their adviser. The questionnaires/survey forms were written in English. It is divided into two parts: the profiling and the survey questions related to the study. The questioning method is in check list form. Researchers gave time to the respondents to answer the questionnaire carefully, honestly, and as accurate as possible.

After the retrieval of the questionnaires, the researchers examined and checked the data. This process was reinforced by a personal interview to the respondent concerned. Assigning of scores was done arbitrarily in the following manner as reflected below: The respondents' answers were categorized into four levels and are individually described as follows:

\begin{tabular}{|l|l|l|}
\hline $\begin{array}{l}\text { Numerical } \\
\text { Equivalent }\end{array}$ & Range Interval & Verbal Description \\
\hline 4 & $3.26-4.00$ & Always (A) \\
\hline 3 & $2.51-3.25$ & Often (O) \\
\hline 2 & $1.76-2.50$ & Sometimes (S) \\
\hline 1 & $1.00-1.75$ & Never (N) \\
\hline
\end{tabular}

The researcher collected and tabulated the data gathered. The data were presented analyzed and interpreted in the light to determine the findings of the study.

All data where based on the answers from the questionnaires and percentage where done on all variables using the following formula:

\section{A. Simple Percentage}

As a first step in the determination of profile of the students as to age, gender, and year level taken of the respondents, the \% was used, with the formula was taken here under:

$\mathrm{P}=\frac{\mathrm{f}}{\boldsymbol{N}} \mathrm{X} 100$

Where:

$\mathrm{P}=$ percentage

$\mathrm{N}=$ total number

$100=$ Constant Facto

\section{B. Weighted Mean}

The weighted mean was used in determining the use of resources, impacts and difficulties of the Offline Search System to the students of Bachelor of Science in Information and Communications Technology. $\mathrm{WM}=\frac{f w}{N}$

Where:

$\mathrm{WM}=$ weighted mean

$\mathrm{N}=$ number of cases

$\mathrm{w}=$ weight for each degree in the scale

$\mathrm{f}=$ frequency

\section{Average Weighted Mean}

The average weighted mean was used to determine the use of general description of resources, impacts and difficulties of the Offline Search System to the students of Bachelor of Science in Information and Communication Technology.

$\mathrm{AWM}=\frac{\Sigma W M}{N}$ 
Where:

AWM $=$ average weighted mean

$\Sigma$ = summation

$\mathrm{WM}=$ weighted mean

$\mathrm{N}=$ number of cases

\section{RESULTS}

This chapter presents, analyses, and interprets the data gathered from the documents and questionnaires. The discussion covers the following:

The order of the presentation and interpretation of data herein follows the sequence in presenting the specific sub-problems in chapter 1, as follows:

Part 1 gives the discussion of the profile of the respondents in relation to the age, gender, status, section.

Part 2 presents the resources that are most commonly used.

Part 3 presents the impacts of using offline search application.

Part 4 presents the difficulties encountered in using other offline search application.

\section{PROFILE OF THE BSICT STUdENTS}

The profile of the respondents was described in terms of age, gender, status, and section.

As shown in Table 3, most of respondents were $15-20$ years old which were 36 of the total respondents. This was followed by the groups of respondents that were belongs to the $21-25$ years old which were 15 . It was followed by the respondents, ages: $31-35$ years old which was 1 . There were no respondents, ages: 26 - 30 years old.

Table 3 Frequency, Percentage and Weighted Mean of the RESPONDENTS ACCORDING TO THEIR AGE

\begin{tabular}{|l|l|l|l|l|l|l|}
\hline Age & $\begin{array}{l}1^{\text {st }} \\
\text { Year }\end{array}$ & $\begin{array}{l}2^{\text {nd }} \\
\text { Year }\end{array}$ & $\begin{array}{l}3^{\text {rd }} \\
\text { Year }\end{array}$ & Total & WM & Percentage \\
\hline $\begin{array}{l}15- \\
20\end{array}$ & 6 & 3 & 27 & 36 & 0.69 & 69 \\
\hline $\begin{array}{l}21- \\
25\end{array}$ & 8 & 3 & 4 & 15 & 0.29 & 29 \\
\hline $\begin{array}{l}26- \\
30\end{array}$ & 0 & 0 & 0 & 0 & 0 & 0 \\
\hline $\begin{array}{l}31- \\
35\end{array}$ & 0 & 1 & 0 & 1 & 0.02 & 2 \\
\hline AWM $=0.25$ & & & & \\
\hline
\end{tabular}

As shown in the Table 4, most of the respondents were female, which were 29 of the total respondents. This is followed by the male respondents which were 23 .

Table 4 Frequency, Percentage and Weighted Mean of the RESPONDENTS ACCORDING TO THEIR GENDER

\begin{tabular}{|l|l|l|l|l|l|l|}
\hline & $\begin{array}{l}1^{\text {st }} \\
\text { Year }\end{array}$ & $\begin{array}{l}2^{\text {nd }} \\
\text { Year }\end{array}$ & $\begin{array}{l}3^{\text {rd }} \\
\text { Year }\end{array}$ & Total & WM & Percentage \\
\hline Male & 5 & 3 & 15 & 23 & 0.44 & 44 \\
\hline Female & 9 & 4 & 16 & 29 & 0.56 & 56 \\
\hline \multicolumn{7}{|l|}{ AWM $=0.5$}
\end{tabular}

As shown in Table 5, most of the respondents were single, which were from 51 of the total respondents. This was followed by the married, which was 1 of the total respondents.

TABle 5 Frequency, Percentage and Weighted Mean of the

\begin{tabular}{|l|l|l|l|l|l|l|}
\hline \multicolumn{7}{|c|}{ RESPONDENTS ACCORDING TO THEIR STATUS } \\
\hline Status & $\begin{array}{l}1^{\text {st }} \\
\text { Year }\end{array}$ & $\begin{array}{l}2^{\text {nd }} \\
\text { Year }\end{array}$ & $\begin{array}{l}3^{\text {rd }} \\
\text { Year }\end{array}$ & Total & WM & Percentage \\
\hline Single & 14 & 6 & 31 & 51 & 0.98 & 98 \\
\hline Married & 0 & 1 & 0 & 1 & 0.02 & 2 \\
\hline AWM $=0.5$ & 0.5 &
\end{tabular}

As shown in Table 6, most of the respondents from section (A) were 36 of the total respondents. This was followed by the section (B) were 16 of the total respondents.

TABle 6 Frequency, Percentage and Weighted MEAN of the RESPONDENTS ACCORDING TO THEIR SECTION

\begin{tabular}{|l|l|l|l|l|l|l|}
\hline Section & $\begin{array}{l}1^{\text {st }} \\
\text { Year }\end{array}$ & $\begin{array}{l}2^{\text {nd }} \\
\text { Year }\end{array}$ & $\begin{array}{l}3^{\text {rd }} \\
\text { Year }\end{array}$ & Total & WM & Percentage \\
\hline A & 14 & 7 & 15 & 36 & 0.69 & $69 \%$ \\
\hline B & 0 & 0 & 16 & 16 & 0.31 & $31 \%$ \\
\hline \multicolumn{7}{|l|}{ AWM $=0.5$}
\end{tabular}

\section{RESOURCES THAT ARE MOST COMMONLY USED}

This aspect presents the status of the student in using the resources that they most commonly used. The respondent answered based on what is on the questionnaire.

Table 7 shows the resources that are mostly used by the BSICT. Indicator number 1, Mobile Phones got the weighted mean of 3.31 with the descriptive rating of Often; indicator number 2, Laptop has2.65 or often; indicator number 3, Personal Computer has 2.25 or sometimes; indicator number 4, Dictionaries has 2.05 or Sometimes.

TABLE 7 FREQUENCY, WeIGHTED MEAN, AND VERBAL DESCRIPTION OF THE RESPONDENTS ACCORDING TO THE RESOURCES THAT ARE MOST COMMONLY

\begin{tabular}{|l|l|l|l|l|l|l|}
\hline Resources & $\begin{array}{l}\text { Never } \\
(1)\end{array}$ & $\begin{array}{l}\text { Sometimes } \\
(2)\end{array}$ & $\begin{array}{l}\text { Often } \\
(3)\end{array}$ & $\begin{array}{l}\text { Always } \\
(4)\end{array}$ & WM & VD \\
\hline $\begin{array}{l}\text { Mobile } \\
\text { Phones }\end{array}$ & 0 & 12 & 12 & 28 & 3.31 & O \\
\hline Laptop & 4 & 22 & 14 & 12 & 2.65 & O \\
\hline $\begin{array}{l}\text { Personal } \\
\text { Computer }\end{array}$ & 15 & 16 & 14 & 7 & 2.25 & $\mathrm{~S}$ \\
\hline $\begin{array}{l}\text { Dictionaries } \\
\text { Average } \\
\begin{array}{l}\text { Weighted } \\
\text { Mean }\end{array}\end{array}$ & 3 & 28 & 13 & 8 & 2.05 & $\mathrm{~S}$ \\
\hline
\end{tabular}

\section{IMPACTS OF USING OFFLINE SEARCH APPLICATION}

This aspect discusses the impacts of using other offline search application. The respondents answered based on what is on the questionnaire.

Table 8 shows the impacts of offline search application to enhance student learning capacity. Indicator number 1, advanced learning for the future studies got the weighted mean of 2.85 with the descriptive rating of Often; indicator number 2, easier access with the aid of this system has 2.69 or Often; indicator number 3, mainly beneficial specifically for BSICT 
students has 2.81 or Often; indicator number 4 , learning other words related to the word searched has 2.77 or Often.

TABle 8 Frequency, Weighted Mean, ANd Verbal Description of THE RESPONDENTS ACCORDING TO THE IMPACTS OF USING OFFLINE

\begin{tabular}{|l|l|l|l|l|l|l|}
\hline \multicolumn{2}{|c|}{ SEARCH APPLICATION } & Impacts Of \\
$\begin{array}{l}\text { Offline } \\
\text { Search } \\
\text { System }\end{array}$ & $\begin{array}{l}\text { Never } \\
(1)\end{array}$ & $\begin{array}{l}\text { Sometimes } \\
(2)\end{array}$ & $\begin{array}{l}\text { Often } \\
(3)\end{array}$ & $\begin{array}{l}\text { Always } \\
(4)\end{array}$ & WM & VD \\
\hline $\begin{array}{l}\text { Advanced } \\
\text { learning for } \\
\text { the future } \\
\text { studies. }\end{array}$ & 0 & 16 & 28 & 8 & 2.85 & O \\
\hline $\begin{array}{l}\text { Easier access } \\
\text { with the aid } \\
\text { of this } \\
\text { system. }\end{array}$ & 1 & 21 & 23 & 7 & 2.69 & O \\
\hline $\begin{array}{l}\text { Mainly } \\
\text { beneficial } \\
\text { specifically } \\
\text { for BSICT } \\
\text { Students. }\end{array}$ & 3 & 14 & 25 & 10 & 2.81 & O \\
\hline $\begin{array}{l}\text { Learning } \\
\text { other words } \\
\text { related to the } \\
\text { word } \\
\text { searched. }\end{array}$ & 0 & 21 & 22 & 9 & 2.77 & O \\
\hline $\begin{array}{l}\text { Average } \\
\text { Weighted } \\
\text { Mean }\end{array}$ & & & & & & \\
\hline
\end{tabular}

\section{DIFFICULTIES ENCOUNTERED IN USING OTHER OFFLINE SEARCH APPLICATION}

This aspect discusses on what is the difficulties encountered in using other offline search application. The respondents answered by checking on what is on the questionnaire.

Table 9 shows the difficulties encountered in using other offline search application. Indicator number 1, there are some not common words unavailable in search system got the weighted mean of 2.33 with the descriptive rating of Sometimes; indicator number 2, word pronunciation is not available in search system has 2.37 or Sometimes; indicator number 3 , indicator number 6 , lack of data's coming from the server has 2.67 or Often; indicator number 7 , difficulty of understanding its definition since there will be no example of sentences which the searched word is used has 2.37 or Sometimes; indicator number 4 , no synonyms and antonyms available has 2.29 or Sometimes; indicator number 5, dictionary-typed but its content is mainly its definition has 2.40 or Sometimes; not updated words and meaning through codes has 2.31 or Sometimes.
TABLE 9

FREQUENCY, WeIGHTED MEAN, AND VERBAL DESCRIPTION OF THE RESPONDENTS ACCORDING TO THE DIFFICULTIES ENCOUNTERED IN USING OTHER OFFLINE SEARCH APPLICATION

\begin{tabular}{|l|l|l|l|l|l|l|}
\hline Identified Difficulties & $\begin{array}{l}\text { Nev } \\
\text { er } \\
(1)\end{array}$ & $\begin{array}{l}\text { Sometim } \\
\text { es } \\
(2)\end{array}$ & $\begin{array}{l}\text { Ofte } \\
\text { n } \\
(3)\end{array}$ & $\begin{array}{l}\text { Alwa } \\
\text { ys } \\
(4)\end{array}$ & $\begin{array}{l}\text { W } \\
\text { M }\end{array}$ & $\begin{array}{l}\text { V } \\
\text { D }\end{array}$ \\
\hline $\begin{array}{l}\text { There are some not } \\
\text { common words } \\
\text { unavailable in search } \\
\text { system. }\end{array}$ & 2 & 33 & 15 & 2 & $\begin{array}{l}2.3 \\
3\end{array}$ & S \\
\hline $\begin{array}{l}\text { Word pronunciation is } \\
\text { not available in search } \\
\text { system. }\end{array}$ & 5 & 27 & 16 & 4 & $\begin{array}{l}2.3 \\
7\end{array}$ & S \\
\hline $\begin{array}{l}\text { Difficulty of } \\
\text { understanding its } \\
\text { definition since there will } \\
\text { be no example of } \\
\text { sentences which the } \\
\text { searched word is used. }\end{array}$ & 2 & 34 & 11 & 5 & $\begin{array}{l}2.3 \\
7\end{array}$ & $\mathrm{~S}$ \\
\hline $\begin{array}{l}\text { No synonyms and } \\
\text { antonyms available. }\end{array}$ & 4 & 31 & 15 & 2 & $\begin{array}{l}2.2 \\
9\end{array}$ & $\mathrm{~S}$ \\
\hline $\begin{array}{l}\text { Dictionary-typed but its } \\
\text { content is mainly its } \\
\text { definition. }\end{array}$ & 1 & 33 & 14 & 4 & $\begin{array}{l}2.4 \\
0\end{array}$ & $\mathrm{~S}$ \\
\hline $\begin{array}{l}\text { Lack of data's coming } \\
\text { from the server. }\end{array}$ & 1 & 38 & 11 & 2 & $\begin{array}{l}2.6 \\
7\end{array}$ & $\mathrm{O}$ \\
\hline $\begin{array}{l}\text { Not updated words and } \\
\text { meaning through codes. }\end{array}$ & 5 & 29 & 15 & 3 & $\begin{array}{l}2.3 \\
1\end{array}$ & $\mathrm{~S}$ \\
\hline Average Weighted Mean & & & $\begin{array}{l}2.3 \\
9\end{array}$ & $\mathrm{~S}$ \\
\hline
\end{tabular}

\section{DISCUSSION}

This chapter provides a summary of the findings of the study, the conclusions based upon the obtained results, as well as the recommendations forwarded in the light of the conclusions arrived. Using the descriptive method of research, the study sought to investigate the relationship of Computer Keyword Search Application for BSICT Students of Cebu Technological University, Daanbantayan Campus: Learning Exercises.

The researchers found out that the majority of the students uses mobile phones as their resources; having a big impact on using the Offline Search System; encountered often difficulties in using other Offline Search System. It is based on the survey that has been conducted by the researchers in the topic.

Based upon the data revealed and presented in the previous chapter, the following findings are hereby stated. From the given questions of the Resources that are most commonly used reveals that questions numbered 1 and 2 got the weighted mean which falls on the rating interval of $2.51-3.50$ which is labeled "Often". Questions numbered 3 and 4 got the weighted mean that falls on the rating interval of $1.51-2.50$ which is labeled "Sometimes". The resources that are most commonly used got the average weighted mean which is 2.68 which means "Often".

From the given questions of the Impacts of using Offline Search Application reveals that all questions numbered 1, 2, 3, and 4 got the weighted mean which falls on the rating interval $2.51-3.50$ which is labeled "Often". The Impacts of using Offline Search System got the average weighted mean which is 2.78 which means "Often". 
Lastly, from the given question of Difficulties encountered in using other Offline Search Application reveals that the question numbered 6 got the weighted mean, which falls on the rating 2.51 - 3.50 which labeled "Often". Questions numbered $1,2,3,4,5$, and 7 got the weighted mean which falls on the rating $1.51-2.50$ which labeled "Sometimes". The difficulties encountered in using other offline search system got the average weighted mean which is 2.39 which means "Sometimes".

\section{CONCLUSION}

From the findings of this system, it is concluded that from the Resources that are most commonly used reveals that the Mobile Phones and Laptops are the most often used resources by the BSICT Students in their everyday studies and everyday search.

From the findings of the Impacts in using Offline Search Application, it is concluded that the positivity of the Offline Search in their studies are Often useful to them and it makes them much better efficient in their everyday class in searching meanings and mostly they can obtained benefits on it.

Lastly, from the findings of the Difficulties encountered in using other Offline Search Application, it is concluded that there are Often difficulties encountered using Offline search, by making a survey of the negativity of it, it is considered that there are some cases or some problems Sometimes encountered and the most Often encounter difficulty is Lack of data's coming from the server.

\section{RECOMMENDATION}

Based on the conclusion made, we recommend that BSICT students should use this application for their everyday studies so that their learning capacity will grow. In addition they can easily use this because it has an easy access of ICT based words, gives correct meaning for the words needed of their study and it is time saving and money saving application.

\section{REFERENCES}

[1] A Books

[2] Frank Rennie, et.al.2013Routledge Group, "e-Learning and Social Networking”

[3] Layon, Tracy R. "Competence Of The On-The-Job Trainees Of The Bachelor Of Science In Hotel, Restaurant, Services Technology Curriculum Of Cebu Technological University: Basis For Skills Enhancement” June 2010

[4] S. Pankaj. 2011 APH Publishing Corp. "Computer Networking"

[5] NikkitheaLayon Hinton “The Job Satisfaction In Relation To The Performance Of The Employees Of The Cebu State College of Science And Technology System Daanbantayan Campus Daanbantayan, Cebu Toward Staff Development” March 2004

[6] Toledo, Mailyn B. "Safety Management of the Engineering Facilities of Cebu-Technological University (CTU Daanbantayan Campus)"2014 B .Unpublished Materials

[7] Jabido Francis Rodney G. Information and Communications Technology Competencies and Capabilities of Schools in
Koronadal City Division as Bases for a Long Term ICT Development Plan. JABIDOBLOCK 1 LOT 5AGREVILLE SUBDIVISION, March 5, 2008.

[8] M. Bergaus, Design Issues for Service Delivery Platforms, DOI 10.1007/978-3-658-10541-9_2, (C) Springer Fachmedien Wiesbaden 2015 https://doi.org/10.1007/978-3-658-10541-9_2

[9] Kuang, Da, "A New Web Search Engine with Learning Hierarchy" (2012).Electronic Thesis and Dissertation Repository. 750 .

[10] Russel K. Miller "The Impact Of Educational Technology on Learner Interactions: A Multiple Case Study Of Elementary Classrooms". 1988

[11] Jo Shan Fu, "ICT in Education: A Critical Literature Review and Its Implications"2004

\section{C.Webliography}

https://findwise.com/keywords/vol43251/

https://www.dcs.bbk.ac.uk

https://eprints.qut.edu.au

http://cpr.indiana.edu/informit

http://ir.lib.uwo.ca

http://www.academia.edu

www.sholink.com

http://www.brainyquote.com/qoutes/keywords/social.html

http://www.wikipidea.org/socialmedia

http://www.ncbi.nlm.nih.gov/pmc/articles/PMC3715786/

http://jcmc.indiana.edu/vol11/issue2/Bryant.html

www.TPRonline.org

http://www.search.informit.com.au

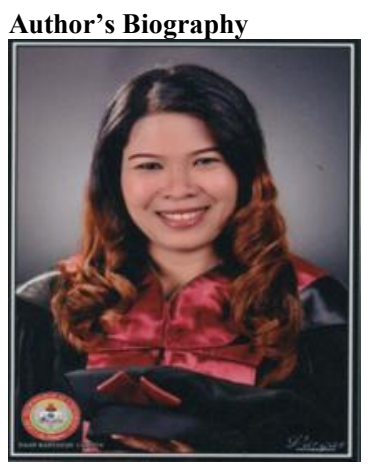

Dr. Nikkithea Layon-Beduya, Principal Author was born in Bogo, City, Philippines. She finished her bachelor's degree as pharmacy in Southwestern University, Cebu, City and passed the PRC board exam. She also took her Diploma in Professional Education at

CTU Daanbantayan Campus and passed the PRC Let examination too.

She finished her Masteral of Arts in Education major in Administration and Supervision at CTU Daanbantayan Campus and the doctorate degree of $\mathrm{PhD}$ in Technology Management in the same University. She also graduated her degree in Master of Arts in teaching Science as her vertical articulated subject. A regular instructor in CTU Daanbantayan Campus earned 24 units of early childhood education at CTU Main Campus Cebu, City, a Law student in the University of the Visayas, Main Campus, Cebu City. Currently enrolled to her second doctoral degree of Developmental Education. 